\title{
The effect of Health Education on Knowledge and Attitude of Female Students in Sohag University about Breast Self-Examination
}

\author{
${ }^{1}$ Hebatullah Ali, ${ }^{2}$ Nesreen Ali Mohammed, ${ }^{2}$ Fouad M.A Yousef \\ ${ }^{1}$ Family Medicine Department, ${ }^{2}$ Public Health and Community Medicine Department, Faculty \\ of Medicine, Sohag, Egypt
}

Submission Date: 05-04-202

Revision Date: 14-05-2021

Acceptance Date: 14-05-2021

\begin{abstract}
Objectives: To evaluate the effect of health education on the knowledge and attitude of breast self-examination (BSE) among fourth-grade non-medical female students in Sohag University. Method: A quasi-experimental pre-test/post-test study design was used. Students were recruited from four faculties in Sohag University; faculties of Arts, Education, Law, and Commerce. Female students were randomly selected, and they were given a pre-test. They were divided into two groups; group A (had a health education session) and group B (no health education session). After one month, all students had a post-test. Scores and levels of knowledge \& attitude were compared between the two groups before and after the health education session. Results: The study included 370 female students. The baseline sociodemographic data, knowledge, and attitude scores were comparable between the two groups before the educational session. In group (A), knowledge scores improved after the educational session in most of the questions and the total knowledge scores, and this improvement was statistically significant. In group (B), there were minimal changes in the post- educational session scores which were not statistically significant. Post-test attitude scores improved in most of the questions for the group (A). For group (B) attitude scores and levels showed little difference in the post-test. Conclusion: Health education sessions improved the knowledge and attitude for BSE.
\end{abstract}

Keywords: Breast cancer, Breast self-examination, Health education.

Correspondence: Hebatullah Ali Email: Hoobaessayed@gmail.com

\section{Introduction}

Breast cancer is a major worldwide health problem as it is the most commonly diagnosed cancer in women. ${ }^{1}$ The best method to increase the rate of early diagnosis of breast carcinoma is to enhance awareness and positive attitudes towards breast cancer and its screening methods. ${ }^{2}$ The commonest screening methods for the early detection of mammary cancer are Breast Self Examination (BSE), Clinical Breast Examination (CBE), and Screening Mammography. Breast self-examination is the most significant screening method in third world countries. ${ }^{3}$ Although the standard for breast cancer screening in developed countries is mammography, it is unaffordable in most middle income and all low-income countries as it costs high because of equipment, personnel, and training. Therefore, in countries with a rising rate of breast cancer (like Egypt), other cheap choices must be given due consideration such as training of lay health care in raising the awareness of the community. ${ }^{4} \quad 5 \quad 6 \quad 7$ Studies that detect breast cancer awareness and BSE practice among Arab women were 
Table 1: Score for knowledge questions before and after the educational session (Group A; No. = 195).

\begin{tabular}{|c|c|c|c|}
\hline Knowledge questions & $\begin{array}{c}\text { Pre-test } \\
\text { score }\end{array}$ & $\begin{array}{c}\text { Post-test } \\
\text { score }\end{array}$ & P-value \\
\hline $\begin{array}{l}\text { 1-BSE should be done every } 2 \text { months } \\
\text { Mean } \pm \text { SD } \\
\text { Median(range) }\end{array}$ & $\begin{array}{c}1.4 \pm 0.76 \\
2(0-2)\end{array}$ & $\begin{array}{c}1.2 \pm 0.95 \\
2(0-2)\end{array}$ & $<0.001$ \\
\hline $\begin{array}{l}\text { 2-BSE must be done between day } 7 \text { until day } 10 \text { after menses } \\
\text { Mean } \pm \text { SD } \\
\text { Median(range) }\end{array}$ & $\begin{array}{c}1.2 \pm 0.59 \\
1(0-2)\end{array}$ & $\begin{array}{c}1.8 \pm 0.47 \\
2(0-2)\end{array}$ & $<0.001$ \\
\hline $\begin{array}{l}\text { 3-BSE should be done in front of the mirror } \\
\text { Mean } \pm \text { SD } \\
\text { Median(range) }\end{array}$ & $\begin{array}{c}1.4 \pm 0.72 \\
2(0-2)\end{array}$ & $\begin{array}{c}1.8 \pm 0.52 \\
2(0-2)\end{array}$ & $<0.001$ \\
\hline $\begin{array}{l}\text { 4-Undress until the waist when doing the BSE } \\
\text { Mean } \pm \text { SD } \\
\text { Median(range) }\end{array}$ & $\begin{array}{l}1.3 \pm 0.7 \\
1(0-2)\end{array}$ & $\begin{array}{c}1.8 \pm 0.57 \\
2(0-2)\end{array}$ & $<0.001$ \\
\hline $\begin{array}{l}\text { 5-Hands should be raised up alternately above the head when doing the } \\
\text { BSE in front of the mirror } \\
\text { Mean } \pm \text { SD } \\
\text { Median(range) }\end{array}$ & $\begin{array}{c}1.5 \pm 0.55 \\
2(0-2)\end{array}$ & $\begin{array}{c}1.9 \pm 0.25 \\
2(0-2)\end{array}$ & $<0.001$ \\
\hline $\begin{array}{l}\text { 6-BSE should be done from the front view only } \\
\text { Mean } \pm \text { SD } \\
\text { Median(range) }\end{array}$ & $\begin{array}{c}1.02 \pm 0.87 \\
1(0-2)\end{array}$ & $\begin{array}{c}1.02 \pm 0.91 \\
1(0-2)\end{array}$ & 0.9 \\
\hline $\begin{array}{l}\text { 7-BSE can be done in a supine position } \\
\text { Mean } \pm \text { SD } \\
\text { Median(range) }\end{array}$ & $\begin{array}{c}1.1 \pm 0.66 \\
1(0-2)\end{array}$ & $\begin{array}{c}1.7 \pm 0.58 \\
2(0-2)\end{array}$ & $<0.001$ \\
\hline $\begin{array}{l}\text { 8-Palpate in the right breast while left-sided lying when doing the BSE } \\
\text { Mean } \pm \text { SD } \\
\text { Median(range) }\end{array}$ & $\begin{array}{c}1.2 \pm 0.64 \\
1(0-2)\end{array}$ & $\begin{array}{c}1.5 \pm 0.74 \\
2(0-2)\end{array}$ & $<0.001$ \\
\hline $\begin{array}{l}\text { 9-Use finger pulps to examine any lumps or thickening of the skin } \\
\text { Mean } \pm \text { SD } \\
\text { Median(range) }\end{array}$ & $\begin{array}{c}1.7 \pm 0.54 \\
2(0-2)\end{array}$ & $\begin{array}{c}1.9 \pm 0.31 \\
2(0-2)\end{array}$ & $<0.001$ \\
\hline $\begin{array}{l}\text { 10-BSE can be done using the vertical strip and circular technique } \\
\text { Mean } \pm \text { SD } \\
\text { Median(range) }\end{array}$ & $\begin{array}{c}1.2 \pm 0.67 \\
1(0-2)\end{array}$ & $\begin{array}{c}1.4 \pm 0.66 \\
1(0-2)\end{array}$ & 0.011 \\
\hline $\begin{array}{l}\text { 11-Need to press on the nipple to check any unusual discharge } \\
\text { Mean } \pm \text { SD } \\
\text { Median(range) }\end{array}$ & $\begin{array}{c}1.6 \pm 0.62 \\
2(0-2)\end{array}$ & $\begin{array}{c}1.7 \pm 0.62 \\
2(0-2)\end{array}$ & 0.231 \\
\hline $\begin{array}{l}\text { 12-BSE includes arm-pit examination to check for any lump } \\
\text { Mean } \pm \text { SD } \\
\text { Median(range) }\end{array}$ & $\begin{array}{c}1.7 \pm 0.56 \\
2(0-2)\end{array}$ & $\begin{array}{c}1.9 \pm 0.34 \\
2(0-2)\end{array}$ & $<0.001$ \\
\hline $\begin{array}{l}\text { 13-Need to observe any unusual change in the shape and size of breast } \\
\text { Mean } \pm \text { SD } \\
\text { Median(range) }\end{array}$ & $\begin{array}{c}1.8 \pm 0.42 \\
2(0-2)\end{array}$ & $\begin{array}{c}1.9 \pm 0.44 \\
2(0-2)\end{array}$ & 0.286 \\
\hline $\begin{array}{l}\text { 14-Retraction of the nipple is a warning sign that should be observed } \\
\text { Mean } \pm \text { SD } \\
\text { Median(range) }\end{array}$ & $\begin{array}{c}1.4 \pm 0.63 \\
2(0-2)\end{array}$ & $\begin{array}{c}1.7 \pm 0.52 \\
2(0-2)\end{array}$ & $<0.001$ \\
\hline $\begin{array}{l}\text { 15-Lump is the early sign for cancer } \\
\text { Mean } \pm \text { SD } \\
\text { Median(range) }\end{array}$ & $\begin{array}{c}1.4 \pm 0.70 \\
2(0-2)\end{array}$ & $\begin{array}{c}1.3 \pm 0.87 \\
2(0-2)\end{array}$ & 0.268 \\
\hline
\end{tabular}

few and indicated a lack in these areas of information among females. ${ }^{8} 910$

The purpose of our study is to estimate the impact of health education on BSE knowledge and attitude among the fourth- grade non-medical female students at Sohag University.

\section{Method}

\begin{tabular}{lllll}
\hline The Egyptian Journal of Community Medicine & Vol. 40 & No. 1 & January & 2022
\end{tabular}


A quasi-experimental pre-test/post-test research design was used in the present study. The study was organized at four faculties of Sohag University which were

Table 2: Scores for knowledge questions before and after the educational session (Group B; No. = 175).

\begin{tabular}{|c|c|c|c|}
\hline Knowledge questions & $\begin{array}{c}\text { Pre-test } \\
\text { score }\end{array}$ & $\begin{array}{l}\text { Post-test } \\
\text { score }\end{array}$ & P-value \\
\hline $\begin{array}{l}\text { 1-BSE should be done every } 2 \text { months } \\
\text { Mean } \pm \text { SD } \\
\text { Median(range) }\end{array}$ & $\begin{array}{c}1.3 \pm 0.73 \\
1(0-2)\end{array}$ & $\begin{array}{c}1.2 \pm 0.75 \\
1(0-2)\end{array}$ & 0.84 \\
\hline $\begin{array}{l}\text { 2-BSE must be done between day } 7 \text { until day } 10 \text { after menses } \\
\text { Mean } \pm \text { SD } \\
\text { Median(range) }\end{array}$ & $\begin{array}{c}1.4 \pm 0.53 \\
1(0-2)\end{array}$ & $\begin{array}{c}1.4 \pm 0.59 \\
1(0-2)\end{array}$ & 0.23 \\
\hline $\begin{array}{l}\text { 3-BSE should be done in front of the mirror } \\
\text { Mean } \pm \text { SD } \\
\text { Median(range) }\end{array}$ & $\begin{array}{c}1.5 \pm 0.57 \\
2(0-2)\end{array}$ & $\begin{array}{c}1.5 \pm 0.74 \\
2(0-2)\end{array}$ & 0.51 \\
\hline $\begin{array}{l}\text { 4-Undress until the waist when doing the BSE } \\
\text { Mean } \pm \text { SD } \\
\text { Median(range) }\end{array}$ & $\begin{array}{c}1.4 \pm 0.67 \\
2(0-2)\end{array}$ & $\begin{array}{c}1.5 \pm 0.67 \\
2(0-2)\end{array}$ & 0.38 \\
\hline $\begin{array}{l}\text { 5-Hands should be raised up alternately above the head when doing the } \\
\text { BSE in front of the mirror } \\
\text { Mean } \pm \text { SD } \\
\text { Median(range) }\end{array}$ & $\begin{array}{c}1.6 \pm 0.60 \\
2(0-2)\end{array}$ & $\begin{array}{c}1.7 \pm 0.56 \\
2(0-2)\end{array}$ & 0.09 \\
\hline $\begin{array}{l}\text { 6-BSE should be done from the front view only } \\
\text { Mean } \pm \text { SD } \\
\text { Median(range) }\end{array}$ & $\begin{array}{c}1.1 \pm 0.89 \\
1(0-2)\end{array}$ & $\begin{array}{c}1.1 \pm 0.80 \\
1(0-2)\end{array}$ & 0.76 \\
\hline $\begin{array}{l}\text { 7-BSE can be done in a supine position } \\
\text { Mean } \pm \text { SD } \\
\text { Median(range) }\end{array}$ & $\begin{array}{c}1.2 \pm 0.59 \\
1(0-2)\end{array}$ & $\begin{array}{c}1.4 \pm 0.69 \\
1(0-2)\end{array}$ & 0.04 \\
\hline $\begin{array}{l}\text { 8-Palpate in the right breast while left-sided lying when doing the BSE } \\
\text { Mean } \pm \text { SD } \\
\text { Median(range) }\end{array}$ & $\begin{array}{c}1.2 \pm 0.61 \\
1(0-2)\end{array}$ & $\begin{array}{c}1.2 \pm 0.68 \\
1(0-2)\end{array}$ & 0.68 \\
\hline $\begin{array}{l}\text { 9-Use finger pulps to examine any lumps or thickening of the skin } \\
\text { Mean } \pm \text { SD } \\
\text { Median(range) }\end{array}$ & $\begin{array}{c}1.6 \pm 0.56 \\
2(0-2)\end{array}$ & $\begin{array}{c}1.6 \pm 0.61 \\
2(0-2)\end{array}$ & 0.73 \\
\hline $\begin{array}{l}\text { 10-BSE can be done using the vertical strip and circular technique } \\
\text { Mean } \pm \text { SD } \\
\text { Median(range) }\end{array}$ & $\begin{array}{c}1.2 \pm 0.56 \\
1(0-2)\end{array}$ & $\begin{array}{c}1.2 \pm 0.55 \\
1(0-2)\end{array}$ & 0.49 \\
\hline $\begin{array}{l}\text { 11-Need to press on the nipple to check any unusual discharge } \\
\text { Mean } \pm \text { SD } \\
\text { Median(range) }\end{array}$ & $\begin{array}{c}1.6 \pm 0.58 \\
2(0-2)\end{array}$ & $\begin{array}{c}1.8 \pm 0.44 \\
2(0-2)\end{array}$ & 0.02 \\
\hline $\begin{array}{l}\text { 12-BSE includes arm-pit examination to check for any lump } \\
\text { Mean } \pm \text { SD } \\
\text { Median(range) }\end{array}$ & $\begin{array}{c}1.7 \pm 0.57 \\
2(0-2)\end{array}$ & $\begin{array}{c}1.7 \pm 0.61 \\
2(0-2)\end{array}$ & 0.35 \\
\hline $\begin{array}{l}\text { 13-Need to observe any unusual change in the shape and size of breast } \\
\text { Mean } \pm \text { SD } \\
\text { Median(range) }\end{array}$ & $\begin{array}{c}1.9 \pm 0.36 \\
2(0-2)\end{array}$ & $\begin{array}{c}1.9 \pm 0.29 \\
2(0-2)\end{array}$ & 0.58 \\
\hline $\begin{array}{l}\text { 14-Retraction of the nipple is a warning sign that should be observed } \\
\text { Mean } \pm \text { SD } \\
\text { Median(range) }\end{array}$ & $\begin{array}{c}1.6 \pm 0.53 \\
2(0-2)\end{array}$ & $\begin{array}{c}1.6 \pm 0.50 \\
2(0-2)\end{array}$ & 0.36 \\
\hline $\begin{array}{l}\text { 15-Lump is the early sign for cancer } \\
\text { Mean } \pm \text { SD } \\
\text { Median(range) }\end{array}$ & $\begin{array}{c}1.4 \pm 0.64 \\
2(0-2)\end{array}$ & $\begin{array}{c}1.3 \pm 0.86 \\
2(0-2)\end{array}$ & 0.02 \\
\hline
\end{tabular}

randomly selected, namely: faculties of Arts, Education, Law and Commerce.
Using a sample size determination table for a survey study developed by James et al, ${ }^{11}$ and assuming alpha levels of 0.05 , the
The Egyptian Journal of Community Medicine
Vol. 40
No. 1
January
2022 
required sample size was calculated as 370 female students. Considering the drop-out rate, we randomly recruited 400 students, 100 from each faculty. After the exclusion of incomplete questionnaires, 370 female students were included in the final analysis.

Table 3: Scores for attitude questions before and after the educational session (Group A; No. = 195).

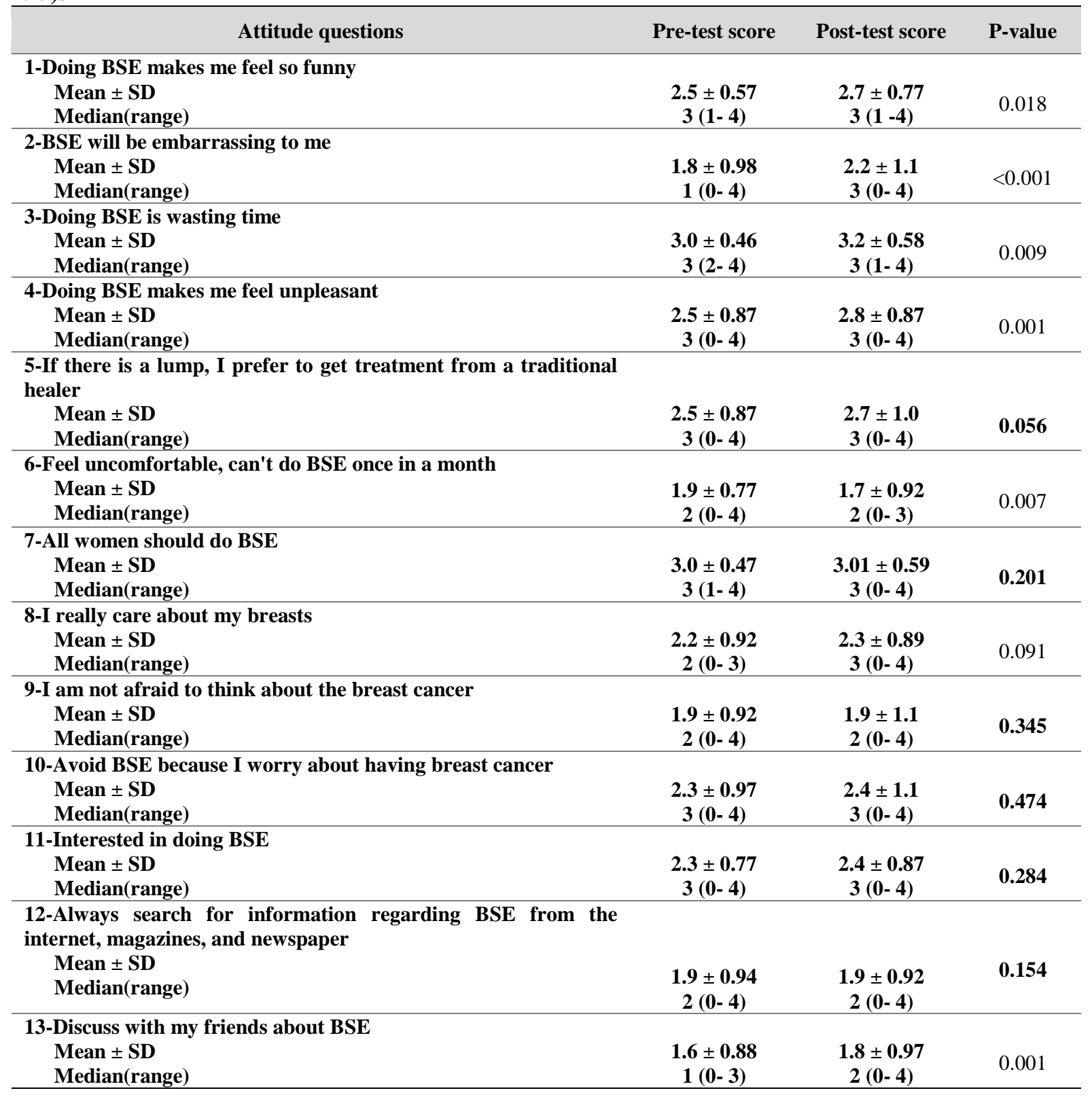

grade, explained the nature and aim of the research to the faculty students. Sections were chosen by cluster random sampling,

The Egyptian Journal of Community Medicine

Vol. 40

No. 1

January

2022 assistant lecturers in each faculty, the researcher entered lectures and sections of the fourth 
were given the pre-test. Each one was asked to leave her name and phone number.
The participated students in each faculty then were randomly divided into two equal

Table 4: Scores for attitude questions before and after the educational session (Group B; No. = 175).

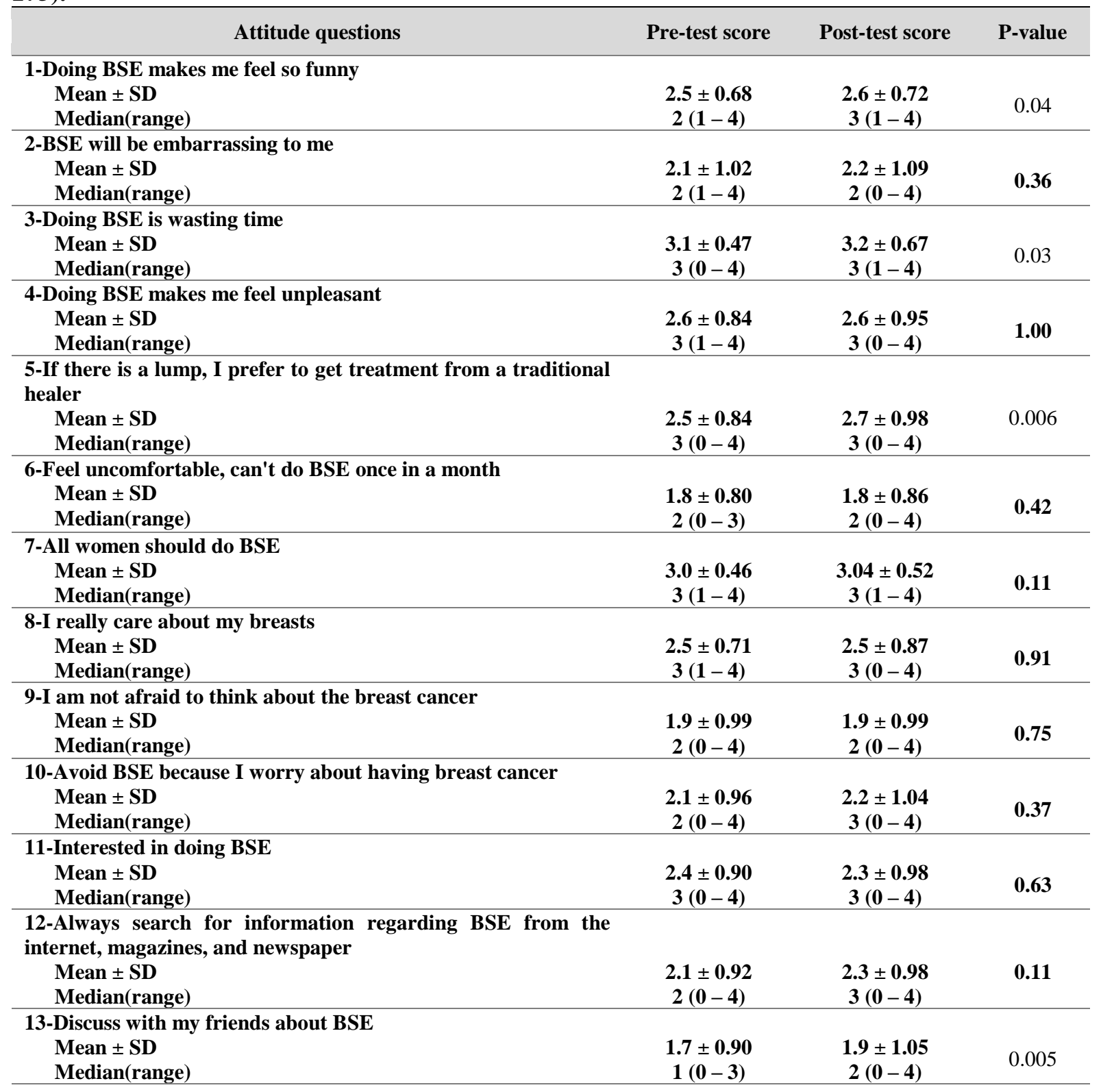

groups: group (A) and group (B). The students in group (A), were contacted and told about the date of the educational setting and registration with the name was done before the beginning of the session, while group (B) students were not subjected to the educational session.
After one month of the educational session, with the cooperation of faculties' lecturers and assistant lecturers, all respondents in both groups who had done the pre-test were given the post-test in lectures and sections. The same questionnaire was given to the students as pre-test and post-test.
The Egyptian Journal of Community Medicine
Vol. 40
No. 1
January
2022 
The health education session included a PowerPoint presentation, which was prepared and given by the researcher and Table (5): Comparison between the studied groups regarding total knowledge and attitude scores of before and after educational session.

\begin{tabular}{|c|c|c|c|}
\hline Scores & Group A & Group B & P-value \\
\hline \multicolumn{4}{|l|}{ Pre- test } \\
\hline $\begin{array}{l}\text { Total knowledge score } \\
\text { Mean } \pm \text { SD } \\
\text { Median (range) } \\
\end{array}$ & $\begin{array}{l}21.1 \pm 3.8 \\
21(11-30)\end{array}$ & $\begin{array}{c}21.1 \pm 3.8 \\
22(15-29)\end{array}$ & 0.07 \\
\hline $\begin{array}{l}\text { Total attitude score } \\
\text { Mean } \pm \text { SD } \\
\text { Median (range) }\end{array}$ & $\begin{array}{c}29.8 \pm 3.6 \\
30(19-41)\end{array}$ & $\begin{array}{c}30.5 \pm 4.4 \\
30(16-42)\end{array}$ & 0.12 \\
\hline \multicolumn{4}{|c|}{ Post-test } \\
\hline $\begin{array}{l}\text { Total knowledge score } \\
\text { Mean } \pm \text { SD } \\
\text { Median (range) } \\
\end{array}$ & $\begin{array}{c}24.6 \pm 3 \\
25(15-30)\end{array}$ & $\begin{array}{c}22 \pm 3.2 \\
22(16-30) \\
\end{array}$ & $<0.001$ \\
\hline $\begin{array}{l}\text { Total attitude score } \\
\text { Mean } \pm \text { SD } \\
\text { Median (range) } \\
\end{array}$ & $\begin{array}{c}31.4 \pm 5.3 \\
31(11-46)\end{array}$ & $\begin{array}{c}31.4 \pm 4.3 \\
32(22-40)\end{array}$ & 0.83 \\
\hline
\end{tabular}

Table (6): Comparison between the pre- and post-educational session total knowledge and attitude scores

\begin{tabular}{|c|c|c|c|}
\hline Scores & Pre-test & Post-test & P-value \\
\hline \multicolumn{4}{|l|}{ Group A } \\
\hline $\begin{array}{c}\text { Total knowledge sco } \\
\text { Mean } \pm \text { SD } \\
\text { Median (Range) }\end{array}$ & $\begin{array}{r}21.1 \pm 3.8 \\
21(11-30)\end{array}$ & $\begin{array}{c}24.6 \pm 3 \\
25(15-30)\end{array}$ & $<0.001$ \\
\hline $\begin{array}{l}\text { Total attitude score } \\
\quad \text { Mean } \pm \text { SD } \\
\text { Median (Range) }\end{array}$ & $\begin{array}{c}29.8 \pm 3.6 \\
30(19-41)\end{array}$ & $\begin{array}{l}31.4 \pm 5.3 \\
31(11-46)\end{array}$ & $<0.001$ \\
\hline Group B & & & \\
\hline $\begin{array}{c}\text { Total knowledge sco } \\
\text { Mean } \pm \text { SD } \\
\text { Median (Range) }\end{array}$ & $\begin{array}{c}21.1 \pm 3.8 \\
22(15-29)\end{array}$ & $\begin{array}{c}22 \pm 3.2 \\
22(16-30)\end{array}$ & 0.45 \\
\hline $\begin{array}{c}\text { Total attitude score } \\
\text { Mean } \pm \text { SD } \\
\text { Median (Range) }\end{array}$ & $\begin{array}{c}30.5 \pm 4.4 \\
30(16-42)\end{array}$ & $\begin{array}{c}31.4 \pm 4.3 \\
32(22-40)\end{array}$ & 0.007 \\
\hline
\end{tabular}

detection) and breast self-examination (meaning, purposes, the importance of practicing, accurate time for performing, frequency and detailed steps of BSE), and a video made by the breast cancer foundation of Egypt called the pink path (https://youtu.be/Lp6o3LQJ9mo).

Additionally, brochures were given to students explaining the steps of the BSE technique (positions, sites to be examined, inspection, and palpation technique and steps).

revised by the supervisors. It includes information about breast cancer (risk factors, warning signs, and methods of early
regarding total knowledge and attitude scores . 
studies with good reliability (Cronbach's (alpha) coefficient $=0.8$ ). The knowledge of participants was assessed through 15 items covering the signs of mammary carcinoma and the method of performing BSE. The attitude of participants towards BSE was determined based on thirteen items.

Scoring system: (1) For knowledge items, the correct response was scored two points, don't know was scored one point, and the incorrect response was scored zero. (2) Regarding attitude questions, using a fivepoint Likert scale, the responses were assigned a numeric value or score. For a positively worded attitude item, scores of '4', ' 3 ', ' '2', ' 1 ' and ' 0 ' were assigned for 'strongly agree', 'agree', 'neutral', 'disagree' and 'strongly disagree' responses, respectively. This scoring was be reversed for the negatively worded attitude items. (3) The total scores were categorized into good and poor levels using a $70 \%$ cutoff point out of the total expected score.

The study outcome measures were: Knowledge questions scores and levels before and after the educational session for both groups, Attitude questions scores and levels before and after the educational session for both groups, Total knowledge and attitude scores (summation of all questions' scores) before and after the educational session in both groups.

\section{Statistical Analysis}

Data were analyzed using IBM SPSS Statistics for Windows version 26.0. Quantitative data were expressed as means \pm standard deviation. Qualitative data were expressed as number and percentage. Quantitative data were tested for normality by the Shapiro-Wilk test. Paired T-test and Independent T-test were used for normally distributed data. Mann Whitney $U$ and Wilcoxon t-test were used for data that were not normally distributed. A 5\% level was chosen as a level of significance in all statistical tests used in the study.

\section{Ethical consideration}

Ethical considerations were observed in each step of the study conducted including verbal consent of participants. Approval of the ethical committee of the Sohag faculty of Medicine was secured. Besides, the objectives and steps of the study were explained to participants. Written consent was obtained from the responsible administrative authorities.

\section{Results}

The study involved a cohort of 370 female students. Students were classified into two groups; group (A) included 195 female students $(52.7 \%)$ while group (B) included 175 female students $(47.3 \%)$. The age range of the study population was $20-28$ years with a mean age of $22 \pm 0.9$ years. More than $90 \%$ of our sample were single females of medium socioeconomic status. Only $13 \%$ of them have a family history of breast cancer. The sample included more or less equal proportions representing the four non-medical faculties included in the study (Arts, Commerce, Education, and Law).

Regarding the difference in knowledge scores pre-and post- educational session, in group (A) knowledge scores improved after the educational session in most of the questions and this improvement was statistically significant. Despite the improvement in questions 11 and 13, it was not statistically significant. On the other hand, the score of question 6 showed no difference. Moreover, the score of the first question indicated statistically significant deterioration after the educational session (Table 1). In group (B), there were minimal changes in the post-test knowledge scores which were not statistically significant. Questions 7 and 11 showed statistically significant improvements. On the contrary, 
question 15 showed a slight statistically significant deterioration in the post-test (Table 2). In terms of attitude towards BSE, in the group (A), post-educational session scores improved in all questions except questions

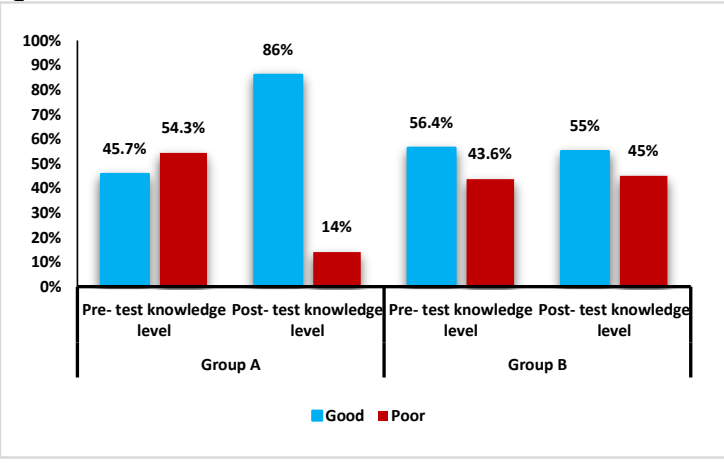

Figure 1: Comparison between the studied groups regarding knowledge levels pre- and post-educational session.

6 and 9, there was a deterioration in their scores. The improvement was statistically significant except for questions $7,10,11$, and 12 (Table 3). Whereas in the group (B), attitude post-test scores minimally increased without being statistically significant except for questions $1,3,5$, and 13. The score of question 4 did not change, while scores of questions 6 and 9 demonstrated little decrease (Table 4).

When the total knowledge and attitude scores were analyzed, both groups were statistically comparable at the baseline with no statistically significant difference. In group (A), the total knowledge and attitude scores improved significantly after the educational session ( $\mathrm{P}$ value $<0.001$ ), while there was a minimal improvement in total knowledge and attitude score in the group (B) $(\mathrm{p}$ values $=0.45$ and 0.007 respectively). The total knowledge and attitude scores were higher in the group (A) after the educational session ( $\mathrm{p}$ values; $<0.001$ and 0.83 respectively) (Tables 5 and $6)$.
Students were classified into poor and good knowledge and attitude levels using the $70 \%$ cut-off value. In group (A), the percentage of students with poor knowledge dropped from $54.3 \%$ before the educational session to $14 \%$ after the educational session, while the percentage of students with good knowledge increased from

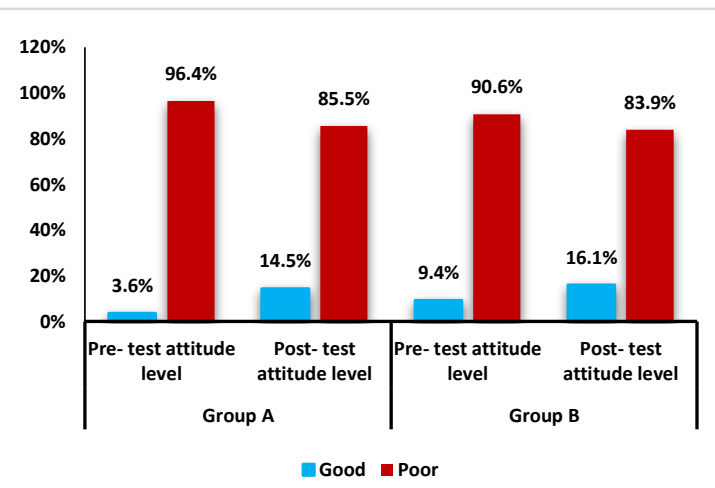

$45.7 \%$ to $86 \%$ after the educational session.

Figure 2: Comparison between the studied groups regarding attitude levels pre- and post-educational session.

On the other hand, changes in knowledge level in the group (B) was minimal. The percentage of students with poor knowledge increased from $43.5 \%$ in the pre-test to $45 \%$ in the post-test, while the percentage of students with good knowledge decreased from $56.4 \%$ to $55 \%$ (Figure 1 ).

Regarding attitude, the percentage of students with poor attitude slightly decreased from $96.4 \%$ before the educational session to $85.5 \%$ after the educational session. Besides, the percentage of students with good attitudes improved from $3.6 \%$ to $14.5 \%$ in group A. Lower changes in attitude level in the group (B) were found, as the percentage of students with poor attitude slightly decreased from $90.6 \%$ in the pre-test to $83.9 \%$ in the post-test and the percentage of students with good attitudes improved from $9.4 \%$ to $16.1 \%$ (Figure 2).

\section{Discussion}

Vol. 40 No. 1

January

2022 
In the current study, we investigated the effect of health education on the knowledge and attitude of BSE. The knowledge of BSE improved significantly after the educational session, whereas attitude towards BSE minimally improved after the educational session. In contrast, there was a minimal change in the knowledge and attitude of BSE in the female students who had no health education educational session.

As the breast self-examination should begin at the age of $20,{ }^{14}$ we thought that this study should be directed to fourth-year female university students in non-medical faculties. Having no medical background would remove any factors that would affect the pre-test results and would show the effectiveness of the education session.

Concerning the knowledge of BSE before the educational session, this study showed that around $54 \%, 44 \%$ of the students in groups A and B respectively, had poor knowledge level. Lower knowledge levels of BSE were reported at the baseline among women in Kuwait, ${ }^{15}$ among school girls in Sri Lanka, ${ }^{16}$ among university female students in Malaysia, ${ }^{17}$ India, ${ }^{13}$ Egypt, ${ }^{18-20}$ Saudi Arabia, ${ }^{21}$ and in school teachers in Iraq. ${ }^{22}$ All these countries are developing countries, and this may reflect the lack of health education provided. On the contrary, other studies that were done in Iran, Turkey, Nigeria, Sudan, and India showed that between $50-95 \%$ of the respondents were aware of BSE and had sufficient information about breast cancer early detection measures. This distinction in baseline values could be due to countries' education and health policy focus on preventive behaviors or maybe a difference in the sample population. ${ }^{23-27}$

Educational measures about BSE are found to be effective ways of increasing the knowledge and practical competence of BSE. There are different measures used in this literature. The current study used a PowerPoint presentation, a video by the breast cancer foundation of Egypt called the pink path, and informative pamphlets.

In group $\mathrm{A}$, the knowledge questions about the right steps, positions, and technique of BSE showed statistically significant improvement except questions eleven (Need to press on the nipple to check any unusual discharge) and thirteen (Need to observe any unusual change in the shape and size of breast), the difference between pre-and post- health education session knowledge scores was statistically significant for most of the knowledge questions and the total knowledge scores. This proves the effectiveness of the health education session in making the students have the right information and details about BSE. Similar improvement was reported in other studies which were done among college students in different countries. $18,19,28-32$

In group $\mathrm{B}$, there were minimal changes in the post-test knowledge questions' scores and total knowledge scores, which were statistically insignificant. Question fifteen (lump is the early sign for cancer) showed a slight statistically significant deterioration in the post-test. This can be because this group had not been exposed to any educational measures that would make a change to their knowledge about BSE. However, scores of knowledge questions five (Hands should be raised alternately above the head when doing the BSE in front of the mirror), seven (BSE can be done in a supine position) and eleven (Need to press on the nipple to check any unusual discharge) showed statistically significant improvements. This can be explained that the students became more interested in the BSE after the pre-test and they may have searched for information about BSE by themselves. Using a cut-off value of $70 \%$, 
post-educational session scores were categorized into poor and good levels. There was a marked improvement in the knowledge levels in the group (A) compared to group (B) who had minimal improvement. This improvement in tandem with the improvement in knowledge scores highlights the value of health education on the practice of BSE.

Regarding post-educational session attitude scores, total attitude scores indicated little increase, and this was statistically significant. Additionally, scores improved in all questions in the group (A) except question six (Feel uncomfortable, can't do BSE once in a month) and nine (I am not afraid to think about breast cancer), there was a deterioration in their scores. This shows that participants are more accepting to do BSE regularly monthly although they still have fear of cancer detection. In group $\mathrm{B}$, only questions one (Doing BSE makes me feel so funny), three (Doing BSE is wasting time), five (If there is a lump, I prefer to get treatment from a traditional healer), and thirteen (Discuss with my friends about BSE) showed little statistically significant improvement posttest. This improvement was reflected in the total attitude scores which statistically increased in the second test. Although these students did not have the educational session, the one-month gap might allow them to think, read and possibly discuss with their friends about BSE after the pretest. Attitude levels indicated little improvement in both groups after the educational session. Other studies conducted by Moodi, Moussa, and Shalaby, Mostafa, and Rezaeian documented the effectiveness of an educational intervention in improving the attitudes of university students towards BSE. ${ }^{18,33-35}$

The advantages of this study are the large sample size and its prospective controlled design. Besides, we compared the pre-and post-educational session results. However, no study goes without limitation. We believe that the narrow age limits between students could be considered a limitation. Additionally, more health educational sessions may be required to bring about greater and more obvious changes in students' attitudes. Thus, it is recommended to develop an educational program at the first year of university about BSE. Also, utilize efficiently all channels of the national mass media (such as television, magazine, newspaper) to raise the community awareness about breast cancer.

\section{Conclusion}

Implementing health education sessions resulted in statistically significant improvement in the knowledge and attitude measures in the group who received the educational session compared to those who had not. Health education is an important tool for improving knowledge and attitudes towards BSE, hence early detection of breast cancer.

\section{References}

1. Ferlay J, Colombet M, Soerjomataram I, et al. Estimating the global cancer incidence and mortality in 2018: GLOBOCAN sources and methods. International journal of cancer. 2019;144(8):1941-1953.

2. Badakhsh M, Balouchi A, Taheri S, Bouya S, Ahmadidarehsima S, Aminifard M. Attitude and Practice Regarding Breast Cancer Early Detection among Iranian Women: A Systematic Review. Asian Pacific journal of cancer prevention : APJCP. 2018;19(1):9-16.

3. DeSantis CE, Ma J, Gaudet MM, et al. Breast cancer statistics, 2019. CA: a cancer journal for clinicians. 2019;69(6):438-451.

4. WHO. Cancer Control: Knowledge into Action: WHO Guide for Effective Programmes: Module 3: Early Detection. Geneva: World 
Health OrganizationCopyright (c) World Health Organization 2007.; 2007.

5. Abuidris DO, Elsheikh A, Ali M, et al. Breast-cancer screening with trained volunteers in a rural area of Sudan: a pilot study. Lancet Oncol. 2013;14(4):363-370.

6. Lewin S, Munabi-Babigumira S, Glenton C, et al. Lay health workers in primary and community health care for maternal and child health and the management of infectious diseases. Cochrane Database Syst Rev. 2010(3):Cd004015.

7. Han HR, Lee H, Kim MT, Kim KB. Tailored lay health worker intervention improves breast cancer screening outcomes in non-adherent Korean-American women. Health Educ Res. 2009;24(2):318-329.

8. Sayed I. HRA-S, Fatimah B. Al Ali1, Kawthar H. Al-Saleh1, Lolowah E. AlHammar1,. Awareness and Attitude among Saudi Females toward Breast Cancer Screening in Al-Ahsa, KSA. The Egyptian Journal of Hospital Medicine. 2018;71(2):2516-2522.

9. Sherma C, Hossfeld D. Breast cancer in manual of oncology. Bosch FX International Union against cancer. Middle East 5th ed Berlin Heidelberg/USA: Springer Verlag. 1990:257276.

10.Osime OC, Okojie O, Aigbekaen ET, Aigbekaen IJ. Knowledge attitude and practice about breast cancer among civil servants in Benin City, Nigeria. Ann Afr Med. 2008;7(4):192-197.

11.James E. Bartlett I, Kotrlik JW, Higgins CC. Organizational Research: DeterminingAppropriate Sample Size in Survey Research. Information Technology, Learning, and Performance Journal. 2001; Vol. 19(No. 1, Spring 2001).

12.Rosmawati NH. Knowledge, attitudes and practice of breast self-examination among women in a suburban area in Terengganu, Malaysia. Asian Pacific journal of cancer prevention : APJCP. 2010;11(6):1503-1508.

13.Doshi D, Reddy BS, Kulkarni S, Karunakar P. Breast Self-examination: Knowledge, Attitude, and Practice among Female Dental Students in Hyderabad City, India. Indian journal of palliative care. 2012;18(1):68-73.
14.Kulungowski AM, Finlayson CA. Chapter 62 - Breast Masses. In: Harken AH, Moore EE, eds. Abernathy's Surgical Secrets (Sixth Edition). Philadelphia: Mosby; 2009:309-313. 15.Saeed RS, Bakir YY, Ali LM. Are women in Kuwait aware of breast cancer and its diagnostic procedures? Asian Pacific journal of cancer prevention : APJCP. 2014;15(15):63076313.

16. Ranasinghe HM, Ranasinghe N, Rodrigo C, Seneviratne RDA, Rajapakse S. Awareness of breast cancer among adolescent girls in Colombo, Sri Lanka: a school based study. BMC Public Health. 2013;13(1):1209.

17. Akhtari-Zavare M, Juni MH, Said SM, Ismail IZ. Beliefs and behavior of Malaysia undergraduate female students in a public university toward breast self-examination practice. Asian Pacific journal of cancer prevention : APJCP. 2013;14(1):57-61.

18. Moussa M, Shalaby NS. Effect of breast self-examination education program on knowledge, attitude, and practice of nursing students. Int $\mathbf{J}$ Res Stud Biosci (IJRSB). 2014;2(6):40-49.

19.Doaa Gharieb Moustafa ESA-A, Nadia Mohamed Taha. Effect of a Breast-Self Examination (BSE) Educational Intervention among Female University Students. American Journal of Nursing Science. 2015;4(4):159-165. 20.Ahmed S, Shrief S. The effect of health promotion program on female breast selfexamination knowledge and practice. Egyptian Nursing Journal. 2019;16(1):25-35.

21.Hussein D.M. ASH, Al-Sogaih Y.S., Alorf S.H., Alaskar, R.S. A-MAM, Alsalhowb W.F., Alibrahim A.K., Saka, M.Y. AAM, Baghirova A., and Hindawi S.I. Breast cancer awareness and breast self-examination inNorthern Saudi Arabia. A preliminary survey. Saudi Med J. 2013;34(7):681-688.

22.Maarab younis Abdullah Al-Fathy Bssam AA ميب. Knowledge, Attitude, and Practice of Breast-Self Examination among School Teachers in Mosul City المعرفة، والموقف، وممارسة فحص الثدي الذاني بين معلمي المدارس في مدينة الموصل

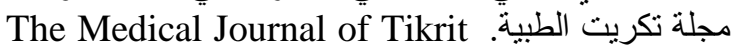
228-221:(2)19;2013. 
23. Memis S, Balkaya NA, Demirkiran F. Knowledge, attitudes, and behaviors of nursing and midwifery students regarding breast selfexamination in Turkey. Oncology nursing forum. 2009;36(1):E39-46.

24.F.O K, Akande T, Osagbemi G. Knowledge, Attitude and Practice of Breast SelfExamination among Female Secondary School Students in Ilorin, Nigeria. European Journal of Scientific Research. 2005;10:42-47.

25.Rahman SHA, Yousif MAHA. Self examination of the breast for early detection of breast cancer: the role of medical students in the Faculty of Medicine - University of Gezira Sudan. 2006.

26.Shalini, Varghese D, Nayak M. Awareness and impact of education on breast self examination among college going girls. Indian journal of palliative care. 2011;17(2):150-154. 27.Samira H, Elrhman A, Magda A, Ahmed Y. Self-Examination of the breast for early detection of breast cancer; the role of Medical students in the faculty of medicine-Sudan. Sudanese Journal of Public Health2006. 2006;1(1):36-42.

28.Masso-Calderón AM, Meneses-Echávez JF, Correa-Bautista JE, Tovar-Cifuentes A, AlbaRamírez PA, Charry-Ángel CE. Effects of an Educational Intervention on Breast SelfExamination, Breast Cancer PreventionRelated Knowledge, and Healthy Lifestyles in Scholars from a Low-Income Area in Bogota, Colombia. Journal of Cancer Education. 2018;33(3):673-679.

29.AbdElgaffar SI AG. The impact of implementing educational program regarding breast self-examination on knowledge and practices of female students of Nursing
Technical Institute of Menoufia University. J Nurs Sci. 2015; 1:44-50.

30. Salaudeen A, Musa O, Oluwale A. Effect of health education on breast cancer and practice of breast self examination among female students of the tertiary institution a Nigerian state. Res J Soc Sci. 2009;4:61-68.

31. Abera H, Mengistu D, Bedaso A. Effectiveness of planned teaching intervention on knowledge and practice of breast selfexamination among first year midwifery students. PloS one. 2017;12(9):e0184636e0184636.

32. Abdel Mowla H, Ahmed M, Abdel E, Ahmed A, Aljaber N, Corresponding A. The Effect of Breast Self-Examination Training Program on the Knowledge, Attitude and Practice among Female Nursing Students at Faculty of Nursing, Alexandria University, Egypt. 2018.

33.Moustafa D. Effect of a Breast-Self Examination (BSE) Educational Intervention among Female University Students. American Journal of Nursing Science. 2015;4:159.

34. Moodi M, Mood MB, Sharifirad GR, Shahnazi H, Sharifzadeh G. Evaluation of breast self-examination program using Health Belief Model in female students. Journal of research in medical sciences: the official journal of Isfahan University of Medical Sciences. 2011;16(3):316.

35.Rezaeian M, Sharifirad G, Mostafavi F, Moodi M, Abbasi MH. The effects of breast cancer educational intervention on knowledge and health beliefs of women 40 years and older, Isfahan, Iran. J Educ Health Promot. 2014;3:4343. 